\title{
Rural Internet Centre (RIC) as Catalysts for Building Knowledge-Based Society - The Case of Northern States of Malaysia
}

\author{
Nor Iadah Yusop, Zahurin Mat Aji, Huda Ibrahim, Rafidah Abd. Razak, \\ and Wan Rozaini Sheik Osman \\ Faculty of Information Technology \\ Universiti Utara Malaysia \\ 06010 UUM Sintok, Kedah, Malaysia \\ \{noriadah, zahurin, huda753, rafidah, rozai174\}@uum.edu.my
}

\begin{abstract}
The creation of Rural Internet Centre (RIC) by the Malaysian government was to provide opportunity and to empower the rural communities in Malaysia. The RIC provides IT skills training and knowledge acquisition programs to the rural community in Malaysia, including women, the elderly, and children. RIC was launched in March 2000 with two centers: Sungai Ayer Tawar in Selangor and Kanowit in Sarawak. By 2006, 42 RICs have been implemented in thirteen states in the country (KTAK, 2006). The Ministry of Energy, Water and Communications (MEWC), Malaysia Post Berhad and Maju Sedunia Digital (MSD) are responsible for the project. The Malaysian government aim to set up 240 centres by the year 2010 which will eventually reaching an estimated 2.8 million members of the rural communities. The management of the centre's operations and activities are given to the local communities. This creates opportunities to the locals to be employed and also provide the chance for acquisition of IT related skills and qualifications. This paper aims at providing an overview over the current RICs implementation with respect to supporting Malaysia government's aspiration towards building the knowledge-based society by the year 2020. RICs could function as the catalyst to achieve this objective. The initial findings on RICs current situations in Northern of Malaysia show that the centres can be further enhanced in order to function as desired.
\end{abstract}

\section{Introduction}

The World Science Forum (2003) defines knowledge-based society as "an innovative and life-long learning society, which possesses a community of scholars, researchers, engineers, technicians, research networks, and firms engaged in research and in production of high-technology goods and service provision". The Knowledge Society in Europe (Knowledge Society Homepage) characterize knowledge-based society as the society who believe that "the most valuable asset is investment in intangible, human and social capital and that the key factors are knowledge and creativity". To build such society, they must be equipped "with the ability to generate and capture new knowledge and to access, absorb, share and efficiently use information, knowledge, 
data, and communication" (European Community and some Asian countries: http://www.sciforum.hu/knowledge_based_society.html). These definitions imply on knowledge creation and production, usage and diffusion, as well as protection, while information and communication technological (ICT) tools allow access to human knowledge. "Knowledge is used to empower and enrich people culturally and materially, and to build a sustainable society" (World Science Forum, 2003), and "the advent of a knowledge-based society requires improved means of communicating and using knowledge and opportunities for lifelong learning" (Citizens and Governance in a knowledge based society: http://ec.europa.eu/research/fp6/index_en.cfm?p=7).

In this sense, we do agree with the European Community and some Asian countries (http://www.sciforum.hu/knowledge_based_society.html) that says "knowledge and information are viewed as global public goods, and they are tools to enrich the learning environment, support everyday experience, and augment instructional resources." To prepare the people to live and work in such society, ICT skills are deemed necessary. Thus, people from all walks of life are of no exception, and the question posed in (http://www.sciforum.hu/knowledge_based_society.html) on whether "building a knowledge-based society seems to have a geographical speciality" is also relevant in Malaysian context, urban and rural. Evers (2001) had mentioned that "Malaysia, or at least its government, has made the move towards a knowledge-based society and economy its primary target". Dr Mahathir (cited in Evers, 2001) did point out that, “... in our pursuit towards developing K-economy, knowledge has to replace labour and capital as the key factors of production of our economy. The challenge for Malaysia is to develop this knowledge amongst our citizens so that our success will be due to the contribution of Malaysian talents and knowledge workers". Hence, Malaysia's dream on knowledge-based society will stay put as a dream if issues on digital divide amongst urban and rural communities remain. Thus, in this respect, ICT plays very important role in bridging the digital divide in realizing the dream.

Apart from being a key enabler for regional and rural success especially in economic and business development, O'Neil (2002) and Thompson (2005) stated that ICT "has also been linked to the aspiration of community empowerment where dimensions include revitalising a sense of community, building regional capacity, enhancing democracy and increasing social capital". Among the initiatives taken to reduce the digital gap is the establishment of multi-purpose community centre (MPCC) or telecentre (Van Belle \& Trusler, 2005). Similar establishment in Malaysia began with turning rural post offices into community Internet classes, and second, creating mini-cyber-cafes through people and corporations. The former project, which started with three pilot sites (Kota Marudu in Sabah, Bau in Sarawak and Sungai Air Tawar in Selangor), were run by Pos Malaysia Berhad (the national mail delivery agency). Each site was equipped with five to seven computers and this number remains until now. To train the orang asli (aborigines) youth and adult community leaders in the use of the Internet and IT equipment, the Community Communication Centre (Komas) that acts an alternative media organization was established (Shom Teoh, 2006). This project emphasized on people and a corporation's participation. The corporations will provide the capital (including the infrastructure (comprising of five PCs and two wireless connections over a VSAT - very small aperture terminal)), and the community will produce the required energy and ideas to encourage the project. Initiatives of this nature have been proven practical by many developing countries, including countries with weak IT infrastructure. 
In general, to formalize these initiatives three approaches have been taken by the Malaysian government: top-down, down-up, and top-down-up (UNESCAP, 2006). Top-down model is initiated by the central government, down-up model is initiated by non-governmental organizations with some collaboration with community-based organizations and government agencies, and the top-down-up is initiated by government, but implemented with strong community participation. Examples of top-down projects are Pusat Internet Desa (Rural Internet Centre - RIC), Medan InfoDesa (MID), Kedai.com, SchoolNet, Universal Service Provision (USP) program, MIMOS projects (Mobile Internet Unit and AgriBazaar), and State government projects. Down-up projects are mostly funded by the Demonstrator Application Grant Scheme (DAGS) include sm@sy, CyberCare, TaniNet, e-Pekak, T-Centre, AKIS/PadiNet, and e-Bario. Top-down-up projects include e-WargaKota, Eagle's Net, Warga Emas Network, Pesarajaya, and e-Upcom. However, the implementation of these Community e-Centres (CeCs) experienced a number of difficulties.

Two studies by the JICA Study Team on RICs initiated by the Ministry of Energy, Water and Communications (MEWC) conducted in March 2003 revealed that the pilot $\mathrm{CeCs}$ suffered from various problems: lack of full-time supervisor, improper physical environment, inadequate maintenance and repair, inadequate publicity of $\mathrm{CeCs}$, low updating frequency of the local homepage, inadequate IT training, resulting in inability to use CeCs by residents with low IT literacy (cited in Noor Bathi, 2005). Hazita et. al (2007) also highlighted one of the problems faced by the RICs users is the inability of the administrators to support them in using the centres' facilities. This is due to the fact that the administrators were not provided with sufficient training in IT. Pertaining to publicity of the centres, Mohd Nizam (2005b) and Wan Rozaini et. al (2007) findings are consistent with the JICA Study Team's. Hence, they also suggested that the government needs to put more effort to ensure a larger percentage of rural community aware of the establishment of these centres.

This paper provides an overview over the current RICs implementation with respect to supporting Malaysia government's aspiration towards building the knowledge-based society by the year 2020 .

\section{Challenges in Rural Internet Centres (RICs) Implementation}

Rural Internet Centre (RIC) is one of the projects set-up by the Malaysian government to bring the Internet to small towns and rural communities in Malaysia, and is run by the MEWC, Malaysia Post Berhad and Maju Sedunia Digital (MSD). The government aims to set up 240 centres by the year 2010 which will eventually reaching an estimated 2.8 million members of the rural communities. This aim corresponds to the government's aspiration to achieve fully developed nation in the year 2020 .

RIC projects were launched in March 2000 with two centers: Sungai Ayer Tawar in Selangor and Kanowit in Sarawak. By 2006, 42 Rural Internet Centres (RICs) have been implemented in thirteen states in the country (KTAK, 2006). RIC provides IT skills training and knowledge acquisition programs to the rural community in Malaysia, including women, the elderly, and children. The number of RICs in each state and the types of facilities, activities and services provided in each centre are dependent on the size of states. 
The studies on RICs in Selangor (Mohd Nizam, 2005a; Mohd Nizam, 2005b) and in Kedah and Perlis (Wan Rozaini et. al, 2007) have shown that the implementation of the centres in that states has been well accepted by the local communities. The centres do not only give the communities an access to the Internet, but also improve their knowledge and skills in ICT. The numbers of RIC users and visitors have increased every day. The centres however, do not have enough ICT resources, for example, PCs, printers, and other peripheral devices. Each centre is only equipped with between five to seven PCs. The centres also have a limited number of staff to administer the RICs. Mohd Nizam's (2005a) study finally concluded that RICs in Selangor and other states should be given more spaces and resources in order to achieve the RICs' objectives.

The assessment of the current RIC operations and usage indicates that the RICs have attracted the interest of the youth compared to the other age categories (Wan Rozaini et. al, 2007; Ezhar et. al, 2007; Hazita et. al, 2007). In terms of gender, they also found that the number of male and female administrators, as well as users, is almost equivalent. Wan Rozaini et. al (2007) found that the Malays outlay the other races as the RICs' administrators and users because the communities surrounding the RICs are mainly the Malays. Similarly, Ezhar et. al (2007) found that the Bidayuh features the majority of users since they are the main race in rural Sarawak. These provide an early indication that the RICs are mainly used by the main races surrounding the RICs.

The management of the centre's operations and activities are given to the local communities. This creates opportunities to the locals to be employed and also provide the chance for acquisition of IT related skills and qualifications. The RICs are managed by full-time administrators. Wan Rozaini et. al (2007) found that almost 46 percents of them are Diploma holders, 27 percents has certificates and the rest with Bachelor and Masters degree. However, these figures do not depict the scenario of entire RICs administrators since the study is conducted only for RICs in Kedah and Perlis. Certificate holders feature the majority users (Ezhar et. al, 2007; Wan Rozaini et. al, 2007).

Regarding the RICs' operations, all studied RICs operate between 8.30 a.m. to 5.30 p.m. on weekdays (Mohd Nizam, 2005b; Wan Rozaini et. al, 2007; Hazita et. al, 2007). All RICs have the basic ICT facilities such as printers, scanners, and internet access. Apart from that, many RICs are equipped also with photocopy and fax machine, LCD projector, digital camera, and reference books. The users also suggested that the number of computers as well as other basic facilities is increased as the current number is insufficient, and the operation hours be extended (Mohd Nizam, 2005b; Wan Rozaini et. al, 2007; Hazita et. al, 2007). These are proposed to allow participation of more users.

Studies by Wan Rozaini et. al (2007) and Hazita et. al (2007) agreed that the common training provided by the RICs include basic computer classes, basic Internet, introduction to Windows and Microsoft Office. In addition, Wan Rozaini et. al (2007) found that webpage development course is also offered. Wan Rozaini et. al (2007) also indicate that among the services provided include giving advices on computer purchase, computer selling and servicing, card printing and writing official letter, e-procurement services, and posting advertisement in webpage. 


\section{Conclusion and Recommendations}

The current RICs' infrastructure and facilities are enough to support their basic operations. However, to offer better services to the communities, these facilities need to be continuously upgraded and improved. Furthermore, to equip the administrators with sufficient skills and abilities, series of training have to be given, either IT related or not. Training modules as suggested by Murray et. al (2001) (cited in UNESCAP (2006) are communication and development, the role of CeCs in development, the role of the CeCs managers/ coordinator, basic business and financial skill, information production skills, needs assessment skills and evaluation (research method), training skills, participation skills, human resource management, and marketing and public relation skills should be taken into consideration to support the government effort in building knowledge-based society. Similarly, continuous trainings that suit communities (user) of different groups and levels should be provided.

To enhance the communities' awareness about the establishment of RICs, aggressive publicity in collaboration with respective agencies and non-government organizations (NGOs) needs to be undertaken through various means such as electronic media, newspapers, and road show to attract a larger percentage of users. In conjunction with the establishment of International Telecommunication Union Asia Pacific Centre in Universiti Utara Malaysia (ITU UUM ASP-CoE) for Rural ICT Development Programme, it can be used as a platform to promote RICs at local and international level. In relation to that, appropriate awareness programs have to be planned and designed.

Regarding the RICs' web pages, the template is provided by the MSD and the maintenance is done by the administrators. However, there are differences in the design and content of each RIC's web pages. Some are mainly informational in which they provide only basic information about the RICs committees, local communities' activities, background of the location, and little information on business opportunities and other e-commerce links. In contrast, some do have additional advanced sections that enable users to link to various online applications especially e-government services such as National Registration Department (JPN), e-procurement, Motor Vehicle Department (JPJ), registrar of commerce, and institutions of higher education. On this account, an effort should be taken to create a standard design so that the targeted communities will get equal opportunities to relevant information and thus bridge the digital gap. In relation to this, analysis of the users' requirements is deemed necessary to enable suitable information or content be included in the websites.

Another important issue related to RIC is its sustainability. For instance, Songan et. al (2004) mentioned that ICTs cannot just be "dropped" in the rural village but need to be accompanied by training and education to be successful and sustainable. Among the aspects outlined in UNESCAP (2006) report include human resource, financial, and social sustainability. In terms of human resource, training of trainers and training of the community members must be carried out. This will create a pool of knowledgeable people from the rural community that can continuously assist the operations of RICs. Currently the RICs are funded by the federal government (Wan Rozaini et. al, 2007). To be financially independent of government funding, the communities must be able to generate their own source of income. This has been proven to work for the e-Bario project (UNESCAP, 2006). This exercise will inculcate the sense of ownership among the community. As a result, it will contribute to the sustainability of the centre. Social sustainability is necessary to ensure the RIC is 
relevant and continually used by the community. Therefore, the RIC services and activities need to be monitored and evaluated to ensure they are relevant to people from all walks of life. In addition, the use of RICs need to be supervised to avoid unethical and illegal activities.

\section{References}

Citizens and Governance in a knowledge based society [14 /01/2007] http://ec.europa.eu/ research/fp6/index_en.cfm?p=7

Tamam, E., Ismail, N., anak Kasa, A.: Pola Pencarian Maklumat dalam Kalangan Belia di Pusat Internet Desa (PID) Sarawak, Presented at the E-Community Research Center Colloquium 2007, 8 February, Universiti Kebangsaan Malaysia, Malaysia (2007)

Azman, H., Setapa, S.H., Mustafa, J., Rizan, T.N., Maasum, T.M., Zabidi, N.A., Ibrahim, K., Norwati, Md., Amir, Z.: Peranan Pusat e-komuniti terhadap Pembangunan Kemahiran: eLiterasi di Kalangan Warga Belia Luar Bandar. Presented at the E-Community Research Center Colloquium 2007, 8 February, Universiti Kebangsaan Malaysia, Malaysia (2007)

Knowledge Society Homepage [14 /01/2007] http://ec.europa.eu/employment_social/knowledge_society/index_en.htm

KTAK , Portal Komuniti Desa (2006) [4 October 2006] http://idesa.net.my

Omar, M.N.: Dasar Perlaksanaan Inisiatif 'Internet Desa': Cabaran dan Implikasi dalam mengurangkan jaringan digital di Malaysia. In: Presented at Workshop 'Membudayakan Masyarakat Jaringan: Cabaran dan Batasan', 16 Jun, Universiti Kebangsaan Malaysia (UKM) (2005a)

Omar, M.N.: Information and Communication Technology Policies in Malaysia: Analysis on Government Measures to Minimise the Digital Divide. In: Proceedings of National ECommunity Seminar 2005, Universiti Kebangsaan Malaysia, (December 6-7, 2005b)

Badarudin, N.B.: Draft Rural ICT Guidebook - Based on Malaysian Experience, presented at Regional Meeting on Effective Design and Delivery of Rural Community ICT Services by UNESCAP/INTAN, 28-30 November 2005, INTAN Bukit Kiara, Kuala Lumpur, Malaysia (2005)

Shom, T.: Rethinking the Digital Divide. The Star Online (March 2, 2006)

Songan, P., Ab Hamid, K., Yeo, A., Gnaniah, J., Zen, H.: Community Informatics: Challenges in Bridging the Digital Divide. In: Khalid, H.M., Helander, M.G., Yeo, A.W. (ed.) Work with Computing System 2004. Damai Science, Kuala Lumpur (2004)

UNESCAP, Guidebook on Developing Community e-Centres in Rural Areas: Based on the Malaysian Experience. United Nations Economic and Social Commission for Asia and the Pacific (2006)

Van Belle, J.P., Trusler, J.: An Interpretivist Case Study of a South African Rural MultiPurpose Community Centre. The Journal of Community Informatics, 1(2) (2005) [14/02/2007] http://www.ci-journal.net/index.php/ciej/article/view/231

Osman, W.R.S., Aji, Z.M., Ibrahim, H., Yusop, N.I., Othman, N.: Ke Arah Memperkasakan Komuniti Luar Bandar: Penilaian Situasi Semasa Pusat Internet Desa (PID). Presented at the E-Community Research Center Colloquium 2007, 8 February, Universiti Kebangsaan Malaysia, Malaysia (2007)

World Science Forum, Budapest, Knowledge and Society, 8-10 November 2003 Budapest, Hungary [17/01/07] http://www.sciforum.hu/index.php?image=update\&content=up_knowledge_based_society 